\title{
宮城・福島両県における慣行田植法の 地域性と光の成立要因に関する研究
}

\section{一慣行田植法に関する諸行事についで—}

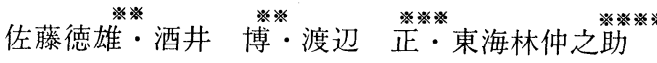 \\ Studies on the Rites and Ceremonies of the Traditional \\ Transplanting Methods of Rice in Miyagi and Fukushima \\ Prefectures.
}

Tokuo SATO, Hiroshi SAKAI, Tadashi WATANABE

and Chunosuke SHOJI

1. はじめに

さきに、全国大学農学部附属農場の共同研究（代 表者神戸大学丹下宗俊・上山 泰両教授) の一環と して、宮城・福島両県における慣行田植法の分布割 合とその成立要因の概要につとて報告した ${ }^{8)}$ 。

今回の報告は慣行田植法に関連する諸行事につい て調査した結果の概要であり、研究費は主として文 部省科学研究費（課題番号 $\left.\begin{array}{llllllll}0 & 3 & 6 & 0 & 2 & 2\end{array}\right)$ にった。

\section{2. 調查方法}

昭和 30 年当時の慣行田植法に関連する諸行事を、 1976 年〜 1997 年にかけて、現地におらて聞 取り調査を行なら一方、文献資料についてる調查を 行なった。

\section{3. 調査結果および考察}

慣行田植法に関連する諸行事として豊程祈願、防 病害虫祈願、田植期間中の祝ら行事などがあげられ る。これらの行事内容について検討してみると、つ ざのようである。

1) 豊穰祈願

(1) 各戸での豊穰祈願

(1) 正月における豊穰祈願
わが国は農をるって立つ国として正月から各戸で 豊榱祈願を行なっていたようである。大晦日には神 棚飞御歳徳神様（正月に迎える神で、米の神様、田 の神様とも、また、先祖神とすいわれている）を祀 り、栗や柳、みずのをなどの枝にいな经やあわん压 （餅花又壮稲の花）をつけて飾り、正月とは御神酒 や餅などを供えて、今年も豊作であるように祈願す るのが一般的である。

宮城県南（白石市など）では正月に釜神様にお田 の神様のお礼（第 1 図）を祀り（宮城県北では初田 植の時神棚に祀る)、それに御神酒や餅を供えたり 蔵の中の種粐俵に芯松を立て、それに鏡餅や餅花を 供えたりして豊穰を祈願している。

福島県会津地方ではサッキといって正月 14 日の 夕方に雪の中に菜や豆殼をさし立てて田植えの真似 事が行なわれており、宮城県宮城郡でも同じような 行事が行なわれているが、とれらの行事す、その年 の豊程を祈願して行なわれたものだといわれている。

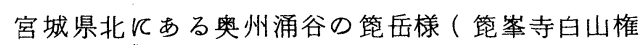
現社)は「五穀豊穰の守り神」として有名であり、 旧正月 25 日の祭典飞県内はもとより県外からも参 择者が訪れ、豊穰祈願が行なわれており、それが今 日まで続いている。そとでは作試し（巫子が的に弓 矢を射り、的中すれば豊作、外れれ何分作とい。

* 昭和 52 年 5 月 26 日受理, 第 12 回講演会で発表

* 東北大学農学部附属農場 宮城県玉造郡鳴子町, 989-67

* ** 福島県農業試験場

※炏娄官城県農政部農業普及課

+ Kawatabi Faculty of Agr., Narugo-cho, Miyagi-ken, 989-67 


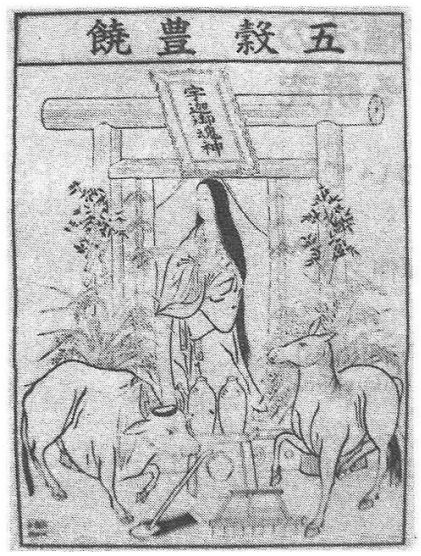

第 1 四お田の神様のお札

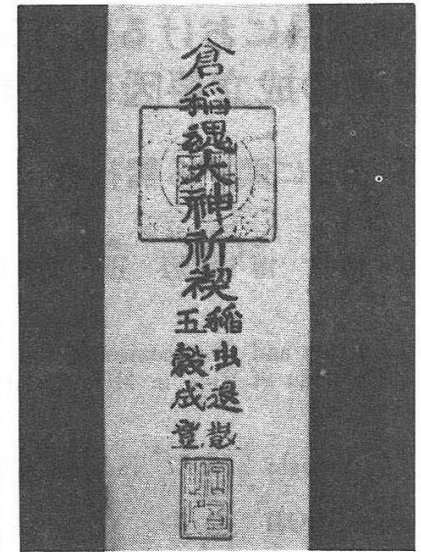

第 2 図啝虫上けのお札

ギの枝にはさんで立て、焼を米を供え るとてろもある。

(3) 田植時飞おける豊䅧新願 初田植には水田の水口にお田の神様 を祀り、豊鈸を祈願するととろる るら れる。

宮城県で壮水丹の水口飞榴虫上けの あ札（第2図）を竹儿比さんで立て。 御神酒と赤飯を供える。そして、植え しま的の時火は、その水口植えた苗 や植え終りの最後の苗（早苗振り苗と いら） $3 \sim 7$ 株を抜いて水洗いし、家

てその年の豊凶を占ら儀式）や種ものの交換（土地 がかわれば作柄がょんとんらことで、交換したい種

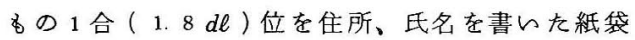
（和紙）飞入れて奉納し、先拝者が奉納した種もの と交換したり、先洋者が奉納した種ものを借りてゅ を、翌年 2 倍（２袋）にして奉納するもので実質的 には種子交換の段割りを果す)などが行なわれてい る。

(2)種まき時における豊穓祈願

ッッジや山桜、ウッギなどの花が咲く頃になると 苗代に種子をまを、その水口にお田の神样を祀り、 苗がすくすく伸びるととと今年す豊作であるととを 新願する行事が両県で広く行なわれている。水口祭 り、苗代祭りなどといわれるるのて、お田の神様の 祀り方は地方炕よ。て異なるが、その代表的なるの を記してみると、つをのょらである。

宮城県では苗代の水口飞ま弊束を立て、まを残っ た種すみを焼き米にして和紙に包んで供えるが、県 北では船形山神社のボンデンや篦岳山篦峯寺のカラ ス子札を竹にはさんで立て、焼さ米を供えるところ 広くみられる。

福島県では苗代の水口に三階松を四角に立て、し め縄を張り、焼を米を供えるが、浜通り南(いわを 市)のように苗代の水口にカラスへイと称する华整 管印のお礼や苗代祭りと書いたお札を竹にはさんで 立て、種李委時期に咲く花(ッッジや山桜、ウッギ ヤマプキ、椿など)を飾り、焼を米を供えるところ や、中通り南（石川郡去と）のよう火苗代の水口に 正月餅を供えた敷を紙（和紙）を三角に切ってッッ
の神棚などに祀ってあるお田の神梯に供え、それに 御神酒々餅を棒げて豊穰を祈願する（その時、熙鍬 を洗ってそれにる御神酒と餅を供劣るので通称「ま んが洗い」といっている)。

宮城狋北の一部（桃生郡など）ではンオリ（サオ リの叱ったもので田の神が山から降りてきて田植え を司る)といって初田植の時に早苗 3 把 (小束) を とり、その上K小さなおにな゙りを 1 個ずつ 3 把にの せて家の神棚に祀ってあるお田の神様に供える。

福島県浜通り南など(いわき市・田村郡)ては初 田植の時、水田にニワトコや楢の枝を立ててお田の 神様を祀り、その下から植え始めたといわれている。 植えじまりの時は植え終りの最後の苗を抜らて水洗 いし、家の神棚に供えるのは宮城県と同じだが、中 通り南るどでは早苗振り苗といって苗代の真中に小 束 2 把分位の苗を残しておいて植えじまいの時、そ の苗をとって芜の神棚飞供完る。

しかし、これらの方法は、昭和 30 年頃には簡略 化されたり、省略化されたととろが多く、宮城県北 では、第3図に示すように、初田植の時苗代から1 〜 3 把の早苗をとって家の神棚に供えるとてろが多 ho

白い苗（しを苗る含む）はお田の神様として珍重 がられ、極力それをみつけて神棚に供えるところも 多く、また、もち苗を供えるとてろる多い。

(2) 部落ぐるみでの豊筫祈願

部落民や部落の代表者（氏子総代など）が神社に 集まり、神前に御神酒や尾頭付をの魚、野菜、海藻 などを供え、豊程を祈願する祭典（神宮祈年祭：2 


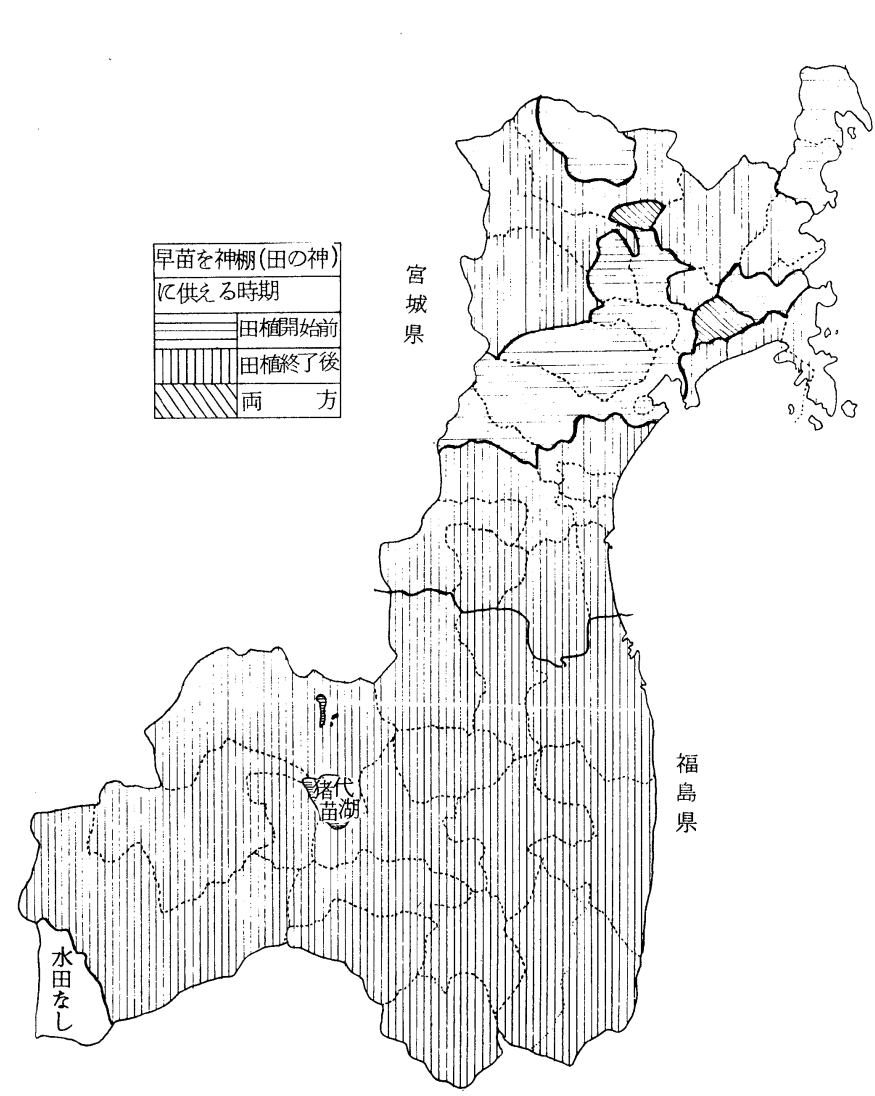

第 3 図早苗を神棚に供える時期

わせなんで、豊かて穣々としてょく 稔るよらに御加護下さいまして秋の

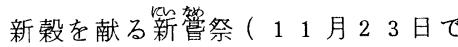
終戦後勤労感謝の日に改められる) を钽かに立派に奉仕させて下さいま せと謹みかしてまって御祭りの詞を 申上げをす。」

2)防病害虫祈願

田植えが終ると虫害が心配され、 虫害を防ぐために各地で「虫送り」 の行事が行なわれている。

古くからウンカなどの害虫駆除法 として「祈禱」や「なじない」など があったが、とくに「虫送り」は全 国的な行事として有名である。

終戦後、B H C や゚ラチオンなど の普及により、ウンカや二化めい虫 などの被害も少なくなったが、虫送 りの風習は最近まで残っていたよう である。

虫送りの方法す地方儿よって異な るが、その代表的なるのについてみ ると、つぎのよらである。

月 17 日、村祈禱： 7 月 1 日) などが行なわれたが、 昭和 30 年頃には葟とんど姿を消している。

神宮祈年祭の祝詞の大要 ${ }^{7}$ 怡つぎのようである。

「今年の農業を始めるのでての部落（市町村など） から結構な御供物を棒げますから御神前に忌み清め まして御供え申上げる衘蓈は、しらけた米（白米の ことを言ら)に粐の米をさし上げ、御酒はたけの高 い、そして腹のふくらんだ酒を入れるミカに溢れる ほど一杯に満たしたのを並べ、野に生えるすのはニ ンシン、カブナのような甘い野菜、ダイコン、ショ ウカのような辛い野菜、海に住むるのは大をな魚、 小さな魚、沖の方の海藻、岸近くの海藻などに至る まで十分にお供え申して今日の吉い日の朝日が瞳々 橴然としてさし昇る爽快な時に御神徳を濽頌して御 祭申上げる事を御満足に御聞入れ御召上り下さいま して天下の人民が手の胘に田の水の泡を垂れ、両股 に泥を㿾さ寄せて耕作する榴を始めとして野菜の一 葉に至るまで、農作物の総てを暴風や洪水の害に遭
宮城県では田植後、ダンゴ、餅、赤飯などをット コ（苞）に入れたものを稲虫と称して竹枝の先に結 んで村境の道端に立てて送るとてろ（仙北：加美郡） や、ダンゴ餅を竹串にさして水田の畔畔に立てて祈 禱するととろ（仙台市・名取郡）ああり、また、子 供達が皿にダンゴを盛り虫送りと書いた旗を立てて 川へ流すところ（宮城郡）や、笹に紙を結んで門口 飞立てるととろ(亘理郡) すある10)。

福島県では田植後、 $5 \mathrm{~cm}$ 長さのット状のワラのダ ンゴを竹串にさして水田の畦畔に立てるとてろが多 いが、浜通り南（いわき市）などでは稲につく害虫 をとって紙袋や木の葉に包んで竹枝の先に結んで子 供達が村境の川に流したといわれている ${ }^{3) 、 4) 。 ~}$

虫送りのととを、福島県会津地方では「いなど送 り」と呼んでいる。

3) 田植期間中の祝い行事

田植えは田の神の降臨を仰ぐ行事であるとして、 初田植、中帳場、早苗振りなど、田植えの折り目毎 
にお祝いをする行事が両県で広く行なわれている。

(1) 田植初日の祝い行事

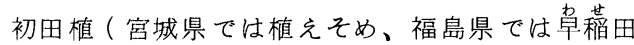
植やさつをなどともいう）といって家々では神棚に お田の神様を祀り、御神酒や赤飯を供えたり、本田 の水口に御神酒や赤领などを供えたりして無事田植 えが終了するととと豊钲を祈願する。

宮城県北では前述のよう飞、初田植の時早苗 1 〜 3 把を取って神前に供えるととろが多く、とれを 「杽暂どり」（本吉郡・気仙沼市）、「そらり」

（桃生郡）などと呼んでんる。

初田植には隣近所や親類などに赤飯などを配って 祝らのが通例である。

（2）田植中間の祝い行事

乫琂場といって田植えの中間に骨休みをかね簡単 に酒盛りをし、一区切りをつけるるのである。

(3) 田植終りの祝い行事

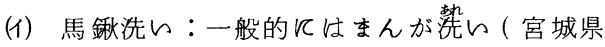

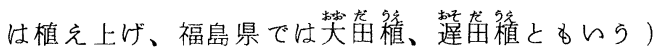
といって、家々の田植えが終了した日に馬鍬を洗い 餅をついて祝う。神前（お田の神様）と馬鈥に御神 酒と餅を供え、無事田植が終了したととを告げると 共に豊稕を祈願する。宮城県南から福島県にかけて は前述のよらに、早苗振り苗といって、田植終了日 飞早苗 1 〜 把をとって神前（お田の神様や釜神様） に供えるとてろが多い。

まんが洗いには隣近所や親類などにさなぶり餅を 配って祝うのが通例である。

(口) 早苗振り：一般的には部落または共同体の 田植終了後、酒、魚、餅などを田植に参加した全員 に振舞うなどして、お祝いと慰労をするものである が、宮城県南から福島県浜通りにかけては、前述の 馬鍬洗いに相当するものを早苗振りといっている。

(-) 大早苗振り：地域社会全体の田植えが終了 したころを見計らい、赤飯などを炏を、地域社会全 体が農休日にして祝ったり、慰労したりする。

4) 田植終了後の農閑日

田植終了後の農閑巨を見計らん、1〜3 日位を農 休日にし、お嫁さんを実家にやって休養させたり、 稼ざ皇治にやって休養させたりする。この農閑 日を骨休み、手やすめ、早苗振り日、お田の神様
(宮城県古川市)、神事（福島県）などといってい る。更に、農閑日以後は、宮城県では三日押し、四

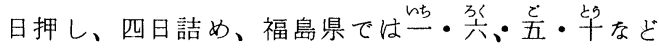
と称し、 4 日ないし 5 日おをどとに午後の半日を農 休日にしているとてろが多い。

宮城・福島両県の慣行田植法に関連する諸行事の 概要は以上のようでするが、これらの行事について

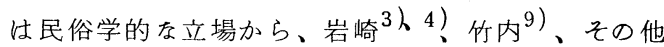
2人6久10）の報告があり、をた、全国的な行事飞つ いては柳田 ${ }^{11}$ )、伊藤 ${ }^{5}$ ）杜 ${ }^{1)}$ などの報告がある。

つざに、全国的な行事との関連について多少ふれ てみたい。

正月飞年神 (正月飞迎える神で、米の神、田の神 とも、をを、先祖神ともいわれる)を祀り、餅花な どを飾り、豊滦を祈願する行事は全国的飞行なわれ ているが、小正月に雪の中に豆殼などをさし立てて 田植えの真似事（サッキ・庭田植など）をする行事 は雪の多い東北地方でみられるものである。

種ま時に苗代の一部に自然木の枝や季節の花な どを捙し、それに焼を米を供えて祀る行事や、田植 時に水田の一部や家の神棚などに餅や赤飯などを供 え、早苗を添える依か、水田に自然木を立てて祀る 行事は、全国住広く分布して未り、また、苗代や本 田に正月に用いた年神の弊などを用いる事例る、か なり広い地域にわたって分布している。家の神棚 （田の神：サの神）に苗を供える時期には、田植開 始前(サオリ系) と田植終了後（サノボリ系）とが あり、全国的に分布している。宮城・福島両県では サノボリ系が多いが、宮城県北ではサオリ系も広く みられる。

神社での豊穰を祈願する祈年祭や新殼を感謝する 新嘗祭は、戦前には国家的行事であり、田植後の豊 穰を祈願するお籠り（村祈譸など）。全国の各地で 行なわれているすのである。

虫送りは全国的な行事として有名であり、虫害を 防ぐために、虫の霊に訴えて虫にその村から立ち退 いてもらうために村境まで送る呪術的行事であるが 宮城・福島両県でみられるよらに、水田の畦畔に串 ダンゴなどをさし立てて祈禱するととろる多い。

田植えは田の神の降臨を仰ぐ行事であるとして、 初田植、中帳場、早苗振りなど、田植えの折り目毎 
にお祝らと慰労をする風習は全国の各地でみられる。

田植終了後の農閑休日（骨休み、手やすめなど） およびその後の農休日は、過酷な労働を瘾すための ものであり、全国に共通するものであるととは言ら まですない。

\section{4. 摘 要}

宮城・福島両県の昭和 30 年当時の慣行田植法に 関連する諸行事について、1 1976 年から 1997 年にかけて調査した。その結果の概要は、つぎの通 りである。

\section{1) 豊穰祈願}

戦前は部落民や部落の代表者などが神社に集まり 豊穰を祈願する祭典（祈年祭や村祈禱など）が行な われたが、昭和 30 年頃には度とんど姿を消してい る。しかし、各戸では、家の神棚に田の神を祀った り、苗代や水田の水口をどに田の神を祀ったりし、 それらに御神酒や赤飯、餅などを供え（家の神棚に は田植開始前または田植終了後に早苗。供える)た りして豊種を祈願する行事が行なわれている。

2) 防病害虫祈願

田植えが終ると虫害が心配され、虫害のないよう 飞各地で虫送りが行なわれるが、その方法は地方に よって異なる。即ち、ダンゴ餅や赤飯などをットに 入れたもの稲虫と称して竹枝の先に結んで村境の 道端に立てて送るとてろや、ダンゴ餅やット状のワ ラダンゴを竹串にさして水田の畦畔に立てて祈る ところもあり、また、稲につく害虫をとって紙袋な どに包んで竹枝の先に吊して川に流すとてろるする。

3）田植期間中の祝い行事

田植えは田の神の降臨を仰ぐ行事であるとして、田 植えの折り目毎にお祝いをする行事がある。田植初 日の初田植、田植中間の中帳場、田植終りの馬鈥洗 い、早苗振り、大早苗振りなどがそれであり、両県 で広く行なわれている。

田植初日には赤飯を炏を、田植終了日とは餅をつ らて苗や御神酒と一緒に家の神棚（田の神など）に 供えると共に、隣近所や親類などに赤飯や餅を配。 て祝らのが通例である。
馬鈥洗いは自家の田植えが終了したとを、早苗振 りは部落または共同体の田植えが終了したとき、大 早苗振りは地域社会全体の田植えが終了したとさの 祝い行事である。

4) 田植終了後の農閑休日など

田植終了後の農閑日を見計らい、1 3 日位を骨 休み、手やすめなどといって休盖し、その後は三日 押し、四日押し、四日詰め、战・桨、童・午などと 称し、4 日ないし 5 日おをどとに午後の半日を農休 日にしているとてろが多い。

\section{5. 引用文献 - 参考文献}

1) 杜宏史(昭和 47 年) 米上日本文化一古代 の風土・民俗をさぐる一・94〜 1221 ・評言社

2) 福島県教育委員会編（昭和 39 年）福島県の 民俗（民俗資料緊急調査報告書）・福島県教育委員 会

3）岩崎敏夫（昭和 48 年）7、日本の民俗、福 島・ 59 9 6 4、132 134 ・第一法規出版 K. K.

4) 岩崎敏夫編（昭和 51 年）東北民俗資料集 (三) ・ 18 8 3 ～ 205 ・萬葉堂書店

5) 伊藤幹治( $\begin{array}{llll}1 & 9 & 7 & 4\end{array}$ 年) 稲作儀礼の研究一琉 同祖論の再検討一・而立書房

6) 宮城県教育委員会編（昭和4 1 年）宮城の民 俗（民俗資料緊急調査報告書）・宮城県教育委員会 7 ) 中西利徳 (昭和 8 年) 祝詞作文講話 $-66 \sim$ 67 - 祝詞作文講話刊行会

8）佐藤徳雄・酒井博 - 渡辺正 - 東海林仲之 助( 19976 年) 宮城 - 福島両県飞小ける慣行田植 法の地域性とその成立要因に関する研究・農作業研 究・第 28 号・ $58 \sim 65$

9 ) 竹内利美（昭和 49 年）4、日本の民俗、宮 城・ $44 \sim 58$ 、 $199 \sim 223$ ・第一法規出版 K. K.

10) 東北民俗の会編（昭和 46 年）陸前の年中行 事・ $15 \sim 231$ ・萬葉堂書店

11) 柳田国男（昭和38 年）定本柳田国男集、第 13 巻 (年中行事覚書) ・ $1 \sim 177$ ・筑摩書房 